\title{
THE INFLUENCE OF THERMAL LOAD ON THE PRINT QUALITY OF SCREEN PRINTED KNITTED FABRICS
}

Branka Ružičić ${ }^{1}$, Mladen Stančić ${ }^{*}$, Nemanja Kašiković², Igor Majnarić 3 , Dragoljub Novaković ${ }^{2}$ Rastko Milošević ${ }^{2}$

(ORIGINAL SCIENTIFIC PAPER) UDC 677.027.423.5

\footnotetext{
${ }^{1}$ University of Banja Luka, Faculty of Technology, Graphic Engineering, Banja Luka, Bosnia and Herzegovina

2University of Novi Sad, Faculty of Technical Sciences, Graphic Engineering and Design, Novi Sad, Serbia

3 University of Zagreb, Faculty of Graphic Arts, Zagreb, Croatia
}

High surface texture of textile materials appears rougher and more porous than other printing substrates which can cause excessive ink penetration. Also, high temperature thermal loads affect the characteristics of printed ink and cause structural changes of the textile substrate material as well. The aim of this paper is to determine the influence of thermal load on the print quality of cotton based fabrics with different knitting types via surface macro nonuniformity and line quality determination of the printed samples. The research results indicated that the thermal load had a negative influence on the line quality parameter and a positive effect on the macro non-uniformity parameter.
Keywords: print mottle, screen printing, line quality, knitted cotton fabric, different knitting type

\section{Introduction}

Colour creates an important visual impression which can provide the basis for decisions in virtually every walk of life. With textile products, the colour often first attracts the consumer and plays an important role in a buying decision [1]. For clothes it is no longer enough to meet only basic functions, such as body protection and functionality, but also to meet the aesthetic and fashion requirements so it can better depict a personal character and lifestyle of the individual [2]. Textile printing can be best described as art and science of decorating a fabric with a colourful pattern or design. The vast majority of textile materials are printed using a screen printing technique. Besides screen printing, textiles can be printed using digital printing and thermal transfer. However, traditional screen printing is the most important printing technique for textile printing [3-5] intended for high productivity and large print circulation which significantly reduce the production costs $[6,7]$. In screen printing, a knitting of screen mesh i.e. a number of threads per $\mathrm{cm}$ is the most relevant factor which defines the printing quality [8]. Mesh number per unit area affects the pattern quality of the printing process. The information about screen mesh density is usually used for determination of the ink volume transfer to the substrate material. Coarse mesh causes some handicaps such as lack of fixing on stencil and the excessive paste transfer onto the fabric [9, 10]. The increase in mesh thread count causes certain changes of the substrate material surface, because during the printing process the ink paste fills a textile material structure which results in the surface roughness change [9]. Textile material is often exposed to various influences such as thermal load, washing process, friction, UV light, etc. It has been proved that thermal load application on textile materials, as well as this process frequency influence the print quality change [11]. The heat treatment of printed textile products is usually applied during the manufacturing process in order to achieve better visual effects. Heat can be applied by any heating element, such as a hand held or an industrial iron. In these processes, the applied heat affects printed ink as well as textile fibres of the substrate material [12]. In this investigation, the attention is placed onto the print mottle and the line quality analysis, as the print quality parameters. The print mottle or solid-tone print uniformity, as a print quality parameter, usually occurs in the manner of systematically structured patterns which the human vision system notices very easily due to its perfect responsiveness to pattern detection [13]. The causes of print mottle are various: inadequate printing pressure, printing speed, substrate material surface roughness, ink transfer and absorption etc. [14]. Print mottle assessment in this research was conducted by GLCM (Grey Level Co-occurrence Matrix) image processing method also known as the grey level spatial dependence matrix. It is a table that keeps track of how often different combinations, pairs of pixel intensities (grey level values) occur in a specific spatial relationship and distance in an analysed image [15]. It was found that contrast, correlation, entropy, energy and homogeneity parameters can be used for the print mottle assessment [15-17]. Low contrast, low correlation, low entropy, high energy and high homogeneity values correspond to the uniform grey

\footnotetext{
*Author address: Mladen Stančić, University of Banja Luka, Faculty of Technology, Graphic Engineering Vojvode Stepe Stepanovića 73, 78000 Banja Luka, Bosnia and Herzegovina

E-mail:mladen.stancic@unibl.rs

The manuscript received: March, 17, 2015.

Paper accepted: April, 14, 2015.
} 
level distribution, i.e., indicate a uniform, smooth surface $[15,18]$. Gebeješ et al. found that the entropy parameter correlates best with the human texture perception and if the entropy value is high, a particular texture becomes more visible and more noticeable. Therefore, it can be concluded that higher entropy values indicate stronger texture patterns which are perceived more easily [19]. The correlation determines a linear dependency of grey levels with those of neighbouring pixels, and it is a quite different calculation of other texture measures described above. As a result, it is independent of them (gives different information) and can often be used profitably in combination with another texture measure. It also has a more intuitive meaning to the actual calculated values: 0 is uncorrelated, 1 is perfectly correlated [20]. The ISO13660 standard suggests blurriness and raggedness as quantifiers of the printed line quality [21]. The most important printed line quality attributes are line width, raggedness and blurriness [22]. Line raggedness indicates the straightness of a printed line. Any geometric distortion is identified as an undesired property of a line, and consequently degrades the quality of the printed image [23]. A ragged edge appears rough or wavy rather than smooth or straight. The lower the raggedness, the better is the line quality [21]. The line quality of less than 12 units of raggedness has a visually unnoticeable difference [23]. An ideal line edge profile should be perfectly straight along the length of a line; any deviation from this gives the appearance of a ragged, jagged or scalloped line [24]. The excessive line raggedness results in lower print sharpness and can also cause an unclear or thicker text [11] which is independent of the line width characteristic [25]. The blurriness is the appearance of being hazy or indistinct in outline. The lower the blurriness, the better is the line quality [21]. The measure of blurriness corresponds to the width of the transition zone between the field and the line. Blurriness increases with the increase of the line width [25].

The aim of this research is to investigate the influence of thermal load and screen mesh tread count on the print quality of the screen printed cotton knitted fabrics with different knitting types. The assessment of the print quality included print mottle and line quality analysis which was performed after the printing process, as well as after the application of the thermal load.

\section{Experimental part}

Three different cotton based textile materials with different knitting types: single, pike and interlock were used. The material characterization was done according to the following standards: material composition (ISO 1833), fabric weight (ISO 3801) and thread count (ISO 7211-2). These substrate material properties are presented in Table 1.

Table 1. Characteristics of the material used in testing

\begin{tabular}{cccccc}
\hline Tests & Type of knitting & Material & Fabric weight & \multicolumn{2}{c}{ Thread count $\left(\mathrm{cm}^{-1}\right)$} \\
& composition $(\%)$ & $\left(\mathrm{g} / \mathrm{m}^{2}\right)$ & $\mathrm{G}_{\mathrm{v}}$ & $\mathrm{G}_{\mathrm{h}}$ \\
\hline Material A & Single & Cotton $100 \%$ & 138 & 14 & 19 \\
Material B & Pike & Cotton $100 \%$ & 185 & 15 & 16 \\
Material C & Interlock & Cotton $100 \%$ & 207 & 12 & 18 \\
Method & & ISO 1833 & ISO 3801 & ISO 7211-2 \\
\hline
\end{tabular}

A special test chart was developed using the Adobe Illustrator CS 5 application. The test chart size was 297 $x 420 \mathrm{~mm}$ and it consisted of various elements of the print quality analysis. The areas sized $2.54 \times 2.54 \mathrm{~cm}$, $100 \%$ tone values of the yellow process colour and 1 pt horizontal black lines were analysed. The samples were printed using the screen printing technique, M\&R Sportsman E Series six-colour printing machine. Pan et al. found that four main parameters had a crucial effect on the screen print quality [26]. These parameters were kept constant during the printing process of all samples. The printing speed was $15 \mathrm{~cm} / \mathrm{sec}$; squeegee hardness was 80 Shore Type A, printing pressure $275.8 \times 103 \mathrm{~Pa}$ and $4 \mathrm{~mm}$ snap-off distance. Sericol Texopaque Classic OP Plastisol (OP058 and OP021) ink was used. Ink fixation was done at the temperature of $160{ }^{\circ} \mathrm{C}$ and the exposure time of 150 seconds.

The printing form was made using printing screen mesh counts of $90,120,140$ and 160 threads per $\mathrm{cm}$ on aluminium tubing frames $(58 \times 84 \mathrm{~cm})$. The size of the stencil without a frame was $50 \times 76 \mathrm{~cm}$. The conventional exposure was conducted using linear positive films. The optical density of transparent areas of the film was 0.3 and 4.1 of opaque areas. The film scanning resolution was five times smaller than printing screen mesh count. Photosensitive Sericol Dirasol 915 emulsion was used. The light exposure was done using metal-halogen UV lamp $(1000 \mathrm{~W})$ at the $1 \mathrm{~m}$ distance from the mesh. The exposure time for each stencil was calculated using the control tape Autotype Exposure Calculator by Sericol Company. The light exposure time for each stencil is presented in Table 2.

Table 2. Exposure time of stencils

\begin{tabular}{cc}
\hline Thread count (threads/cm) & Light Exposure time (min) \\
\hline 90 & 3 \\
120 & 2,6 \\
140 & 1,6 \\
160 & 1,3 \\
\hline
\end{tabular}


The samples were heat treated according to standard ISO 105-X11:1994, using a thermal press MAGNET RV. Time (15 s) and contact pressure (850 daN) were constant during the experiment. The samples were exposed to the temperature of $130{ }^{\circ} \mathrm{C}$. All the samples were scanned and measured repeatedly two times, before and after thermal load. The samples were scanned using flatbed scanner Canon CanoScan 5600F. Scanning resolution was set at $600 \mathrm{spi}$ and auto correction was turned off. Image elements of the significance to this measurement were saved as separate TIFF files and they were analysed afterwards. Scanned samples were subjected to GLCM analysis for obtaining quantitative solid-tone print uniformity results. Applied MATLAB function proposed by Uppuluri [27] provides information about 22 GLCM parameters, out of which the most relevant and used in literature, as well as in this investigation are: contrast, correlation, entropy, energy and homogeneity, as suggested in references $[15,18,28]$. Those five parameters should be interpreted as follows: low values of contrast, correlation and entropy parameters, while high values of energy and homogeneity parameters correspond to a uniform grey level distribution, indicating a uniform solid-tone print surface $[15,18]$. Line measurements were performed with the Personal IAS Image Analysis System, recently introduced by QEA. This device quantifies comprehensive print quality attributes according to ISO 13660:2001 [29].

\section{Results and discussion}

This section of the paper will present obtained GLCM analysis results of different solid-tone patches printed on different knitting type cotton textile materials with yellow ink, using four different mesh thread counts. After the printing process, the printed samples were exposed to high temperature thermal load.
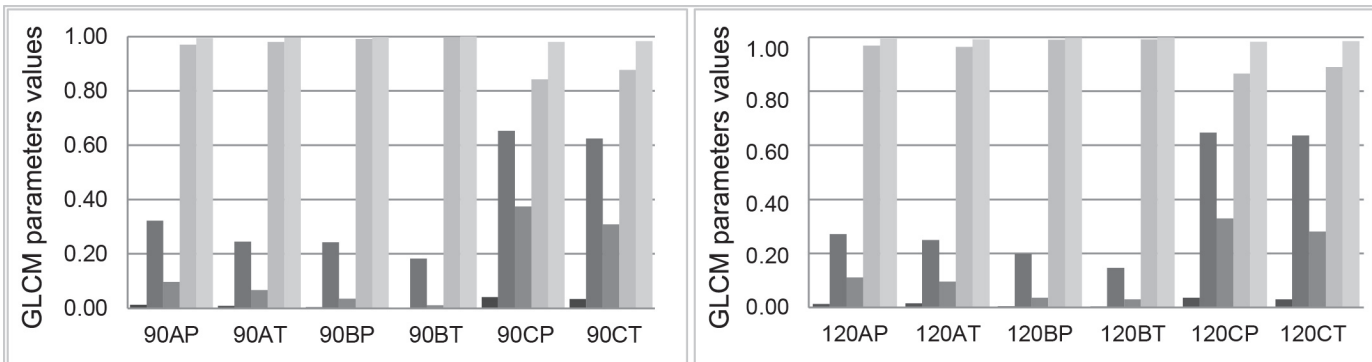

a) Material

b)
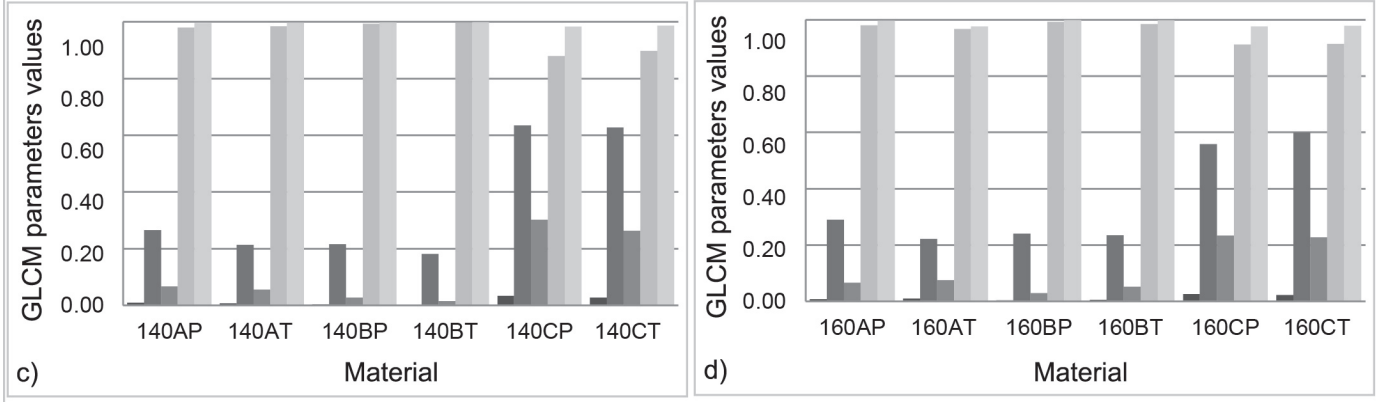

- contrast $\backsim$ correlation $\backsim$ entropy $\llbracket$ energy $\llbracket$ homogeneity

Figure 1. GLCM parameters comparison for the samples printed using four different thread counts on cotton textile materials with different knitting and exposed to high temperature: a) 90 threads/cm, b) 120 threads $/ \mathrm{cm}, \mathrm{c}) 140$ threads/cm, d) 160 threads $/ \mathrm{cm}$.

Note: Numbers 90/120/140/160 represent the thread count; A/B/C represent materials with different knitting; $\mathrm{P}$ is a mark of the printed sample; $\mathrm{T}$ is a mark of the sample measured after thermal load.

In Figure 1 the results of GLCM Matlab function application on scanned samples are presented. Based on these results, all samples have low contrast, correlation and entropy and high energy and homogeneity values which leads to the conclusion that these samples have a good solid-tone print uniformity, i.e. low print mottle. It can be noticed that material $C$ possesses significantly higher values of contrast, correlation and entropy parameters and lower ones concerning energy and homogeneity pa- rameters. This indicates the higher print mottle presence on the samples printed with each screen mesh thread count on this material. Comparing the samples before and after thermal load, certain differences for all GLCM parameters can be noticed which indicates that high temperature has an impact on the printed samples structural arrangement of the surface. Contrast, correlation and entropy parameter values declined for all substrate materials and three out of four mesh thread counts were 
used (90 threads/cm, 120 threads/cm and 140 threads/ $\mathrm{cm}$ ) after thermal load, while energy and homogeneity parameter values increased. It leads to the conclusion that after high temperature and pressure impact, the texture becomes less visible resulting in print mottle diminishing. Exceptions are the samples printed using 160 threads/cm mesh, where GLCM parameter values have a reverse trend i.e. thermal load contributes to a higher print mottle level. It can be assumed that due to the high viscosity of screen printing inks, a lower amount of ink fills the area between the yarns of the fabric and the ink mostly retains on the fabric surface. Therefore, the use of higher mesh thread count will produce a lower amount of ink and thus a thinner layer of ink will be transfered onto the fabric surface, which leads to higher non uniformity of the surface. The lowest mesh thread count will produce the thickest ink layer, thus best filling the holes in the cotton fabric. However, in this case the problem of excessive thickness of ink causes a poor vertical lift of the screen in the zone after printing, which usually results in an uneven surface. Therefore, it is evident from the results that the medium screen printing mesh thread count gives the best results.

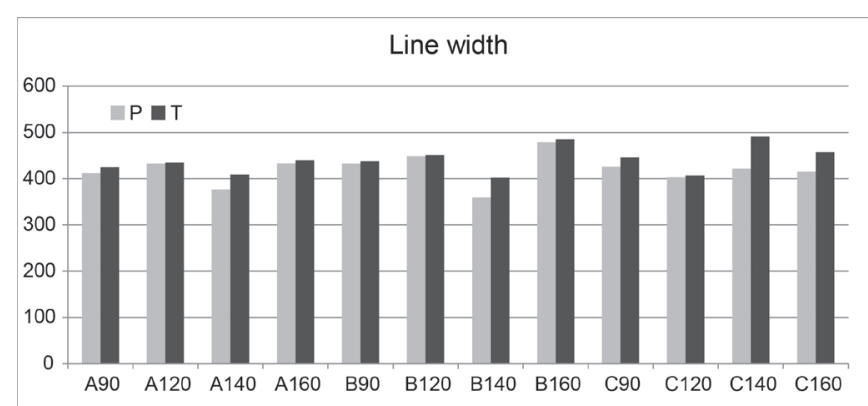

Figure 2. Line width comparison for the samples printed using four different thread counts on cotton textile materials with different knitting and exposed to high temperature

Note: Numbers 90/120/140/160 represent the thread count; $\mathrm{A} / \mathrm{B} / \mathrm{C}$ represent materials with different knitting; $\mathrm{P}$ is the mark of the printed sample; $T$ is the mark of the sample measured after thermal load.

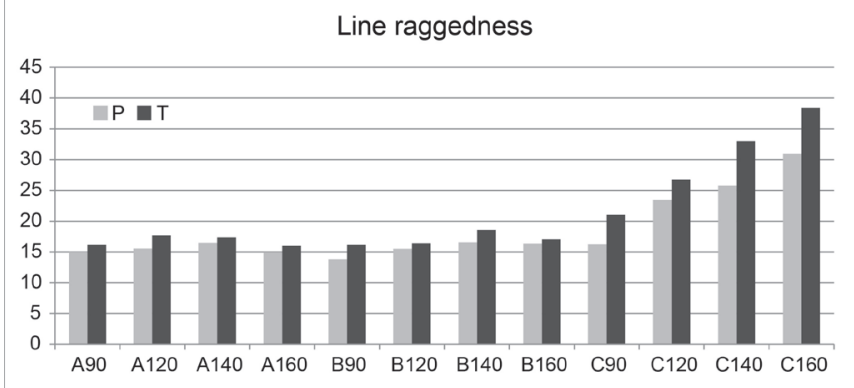

Figure 3. Line raggedness comparison for the samples printed using four different thread counts on cotton textile materials with different knitting and exposed to high temperature

Note: Numbers 90/120/140/160 represent the thread count; $\mathrm{A} / \mathrm{B} / \mathrm{C}$ represent materials with different knitting; $\mathrm{P}$ is the mark of the printed sample; $T$ is the mark of the sample measured after thermal load.

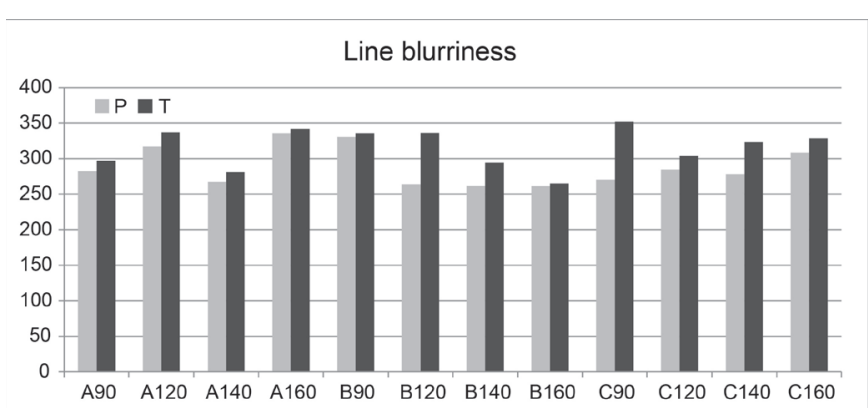

Figure 4. Line blurriness comparison for the samples printed using four different thread counts on cotton textile materials with different knitting and exposed to high temperature

Note: Numbers 90/120/140/160 represent the thread count; $\mathrm{A} / \mathrm{B} / \mathrm{C}$ represent materials with different knitting; $\mathrm{P}$ is the mark of the printed sample; $\mathrm{T}$ is the mark of the sample measured after thermal load.

In Figures 2-4 the line quality parameters results of the printed samples before and after thermal load are shown. It can be noticed that the values of all considered line quality parameters (line width, raggedness and blurriness) are higher after thermal load.

\section{Conclusion}

After the analysis of the thermal load impact on the print quality parameters of cotton material with different knitting, certain conclusions can be made. The aim of the investigation was to compare the same printed samples before and after thermal load, to reveal to what extent a high temperature affects the line quality and the uniformity of the solid-tone print area. Yellow process colour by itself is very complex, with a highly pronounced brightness that could be sensitive to external stimuli as light and heat. Also, it is the colour with the highest pigment content in comparison to other process colours. Based on the print mottle analysis results, all samples have low parameter values for contrast, correlation and entropy, and high energy and homogeneity which lead to the conclusion that these samples have relatively low non-uniformity. After subjecting the samples to the thermal load, the parameter values change are noticeable. Those changes brought better results of the printed surface uniformity characteristic, which leads to the conclusion that high temperature lowers the print mottle. The only difference that should be pointed out is that high thread count mesh let through the lower amount of ink during the printing process and this is what caused the transfer of the lower ink layer to the substrate surface. This caused a high amount of the print mottle on the printed sample which the subsequent thermal load diminished. Regarding the knitting type of the substrate materials it can be concluded that material B possessed the lowest level of print mottle, while the highest print mottle level was recorded on material $\mathrm{C}$. This can be related to the material surface structure, specifically the material $\mathrm{C}$ had "very rough" knitting, which contributed to its higher surface roughness. 
The comparison of the line quality parameter values before and after subjecting the samples to thermal load showed that line width, raggedness and blurriness have higher values after thermal load, i.e. the line quality after thermal load drops. Line raggedness for all samples is higher than 12, which indicates that these print imperfections are visible. The reduction of line sharpness occurs due to bleeding of inks caused by ink melting, which is influenced by high temperatures.

In order to broaden current knowledge in this scientific area, our plan is to conduct the investigations that include the washing influence on different textile material substrates, which will provide insight into the effect of structural characteristics of a textile substrate material on the print quality. Future research should be directed to utilization of different process colours, different thermal load temperatures, another printing technique (e.g. ink-jet) as well as the introduction of pre-treatment of textile materials, which may provide better results.

\section{Acknowledgements}

The research is supported by the Ministry of Education, Science and Technological Development of the Republic of Serbia, project number: 35027 "Development of software model for scientific and production improvement in graphic industry" and project CEEPUS III RS0704-03-1415, "Research and Education in the Field of Graphic Engineering and Design“.

\section{References}

[1] JH. Bae, Color in Ink-Jet Printing: Influence of Structural and Optical Characteristics of Textiles. PhD Thesis, Textile Technology Management, North Carolina State University, 2007.

[2] D. Grujić, Uticaj svojstava materijala na toplotno fiziološku udobnost odjeće. PhD Thesis. Fakulteta za strojništvo, Univerza v Mariboru, 2010.

[3] D. Onar Çatal, A. T. Özgüney, E. P. Akçakoca Kumbasar, The influence of rheological properties of the pretreatment thickeners on ink-jet printing quality, Tekstil ve Konfeksiyon, 22 (4) (2012) 309-316.

[4] N. Kašiković, D. Novaković, I. Karlović, G. Vladić, Influence of ink layers on the quality of ink jet printed textile materials, Tekstil ve Konfeksiyon, 22 (2) (2012) 115-124.

[5] S. Kiatkamjornwong, P. Putthimai, H. Noguchi, Comparison of textile print quality between inkjet and screen printings, Surface Coatings International Part B: Coatings Transactions, 88 (1) (2005) 25-34.

[6] T. M. Lee, Y. J. Choi, S. Y. Nam, C. W. You, D. Y. Na, H. C. Choi, D. Y. Shin, K. Y. Kim, K. I. Jung, Colour filter patterned by screen printing, Thin Solid Films, 516 (21) (2008) 7875-7880.

[7] F. Krebs, M. Jørgensen, K. Norrman, O. Hagemann, J. Alstrup, T. Nielsen, J. Fyenbo, K. Larsen, J. Kristensen, A complete process for production of flexible large area polymer solar cells entirely using screen printing - First public demonstration, Solar Energy Materials and Solar Cells, 93 (4) (2009) 422-441.
[8] M. Stančić, D. Novaković, I. Tomić, I. Karlović, Influence of Substrate and Screen Thread Count on Reproduction of Image Elements in Screen Printing, Acta Graphica, 23 (1-2) (2012) 1-12.

[9] N. Kašiković, G. Vladić, R. Milošević, D. Novaković, M. Stančić, Analysis of change in surface roughness of samples printed using screen printing with variable mesh type, Xlth Symposium on Graphic Arts, Conference Proceedings, University of Pardubice, Department of Graphic Arts and Photophysics, (2013) 127-132.

[10] R. Gemci, M. Kurt, H. H. Solak, S. Serin, Printing of cellulose-based fabrics with sodium hydroxide and investigating color efficiency and fastness properties of these fabrics, Tekstil ve Konfeksiyon, 22 (3) (2012) 240247.

[11] M. Stančić, N. Kašiković, D. Novaković, R. Milošević, D. Grujić, Thermal load effect on print quality of ink jet printined textile materials, Journal of Graphic Engineering and Design, 4 (2) (2013) 27-33.

[12] N. Kašiković, D. Novaković, N. Milić, G. Vladić, Ž. Zeljković, M. Stančić, Thermovision and spectrophotometric analysis of ink volume and material characteristics influence on colour changes of heat treated printed substrates, Tehnički vjesnik, 22 (1) (2015), 33-41.

[13] J. Petersson, A Review of Perceptual Image Quality, Thesis. Department of Science and Technology, Linkoping University Electronic Press, 2005.

[14] M. Kawasaki, M. Ishisaki, Investigation into the Cause of Print Mottle in Halftone Dots of Coated Paper: Effect of Optical Dot Gain Non-uniformity, Japan Tappi Journal, 63 (11) (2009) 1362-1373.

[15] A. Hladnik, M. Lazar, Paper and board surface roughness characterization using laser profilometry and gray level cooccurrence matrix, Nordic Pulp and Paper Research Journal, 26 (1) (2011) 99-105.

[16] C. Fahlcrantz, On the Evaluation of Print Mottle, Thesis. School of Computer Science and Communication, Stockholm, Sweden, 2005

[17] I. Jurič, D. Novaković, I. Karlović, I. Tomić, Influence of gloss and surface roughness of coated ink jet papers on print uniformity, Acta Graphica, 23 (3-4) (2013) 85-92.

[18] Y. Chen, Image analysis methods for paper formation evaluation, Thesis. University of Toronto, Canada, 1998.

[19] A. Gebeješ, I. Tomić, R. Huertas, M. Stepanić, A preliminary perceptual scale for texture feature parameters, Proceedings of the 6th International Symposium on Graphic Engineering and Design, Faculty of Technical Science, Novi Sad, Serbia (2012) 195-202

[20] R. Dutta, A. Stein, N. R. Patel, Delineation of diseased tea patches using MXL and texture based classification, The International Archives of the Photogrammetry, Remote Sensing and Spatial Information Sciences, 37 (B4) (2008) 1693-1700.

[21] Y. Zhang, Z. Liu, Y. Cao, R. Li, Y. Jing, Impact of binder composition on Inkjet printing paper, BioResources, 10 (1) (2015) 1462-1476.

[22] J. C. Briggs, M.K. Tse, Beyond density and color: Print quality measurement using a new handheld instrument, Proceedings of ICIS 02: International Congress of Imaging Science, Tokyo, Japan (2002)

[23] A. Dhopade, Image quality assessment according to ISO 13660 and ISO 19751, Test Target 9 (2009) 43-50.

[24] W. Wu, E. N. Dalal, Perception-based Line Quality Measurement, Electronic Imaging, International Society 
for Optics and Photonics (2005) 111-122.

[25] Breathing Color, Print Quality Evaluation, 2014 [Online] [https://www.breathingcolor.com/page/print-qualityevaluation/], (last request 28.02.2015)

[26] J. Pan, G. Tonkay, A. Quintero, Screen printing process design of experiments for fine line printing of thick film ceramic substrates, Proceedings of International Symposium on Microelectronics, San Diego, California, USA, (1998) 264-269.

[27] A. Uppuluri, GLCM texture features, 2008 [Online] [http:// www.mathworks.com/matlabcentral/fileexchange/22187glcm-texture-features], (last request 28.02.2015)
[28] A. Hladnik, G. Krumpak, M. Debeljak, D. G. Svetec Assessment of paper surface topography and print mottling by texture analysis, Proceedings of ImageJ User \& Developer Conference, Luxembourg, 2010

[29] I. Jurič, I. Karlović, I. Tomić, S. Zdravković, Visual experience of graininess, Proceedings of the 7th International Symposium on Graphic Engineering and Design, Faculty of Technical Science, Novi Sad, Serbia (2014) 267-271.

Izvod

\section{UTICAJ TOPLOTNOG DEJSTVA NA KVALITET OTISKA DOBIJENIH TEHNIKOM SITO ŠTAMPE NA TRIKOTAŽI}

Branka Ružičić1, Mladen Stančić ${ }^{*}$, Nemanja Kašiković², Igor Majnarić ${ }^{3}$, Dragoljub Novaković2, Rastko Milošević

(ORIGINALNI NAUČNI RAD) UDK 677.027.423.5

\footnotetext{
${ }^{1}$ Univerzitet u Banja Luci, Tehnološki fakultet, Grafičko inženjerstvo i dizajn, Banja Luka, Bosna i Hercegovina

2Univerzitet u Novom Sadu, Fakultet tehničkih nauka, Grafičko inženjerstvo i dizajn, Novi Sad, Srbija
}

3 Univerzitet u Zagrebu, Grafički fakultet, Zagreb, Hrvatska

Gruba tekstura površine, kao i velika poroznost tekstilnih materijala, u odnosu na ostale vrste štamparskih podloga, mogu dovesti do pretjeranog prodora boje. Pored toga, visoke temperature toplotne obrade utiču na karakteristike boje odštampanih uzoraka, kao i na strukturne promjene u tekstilnoj podlozi. Cilj ovog rada je utvrđivanje uticaja toplotne obrade na kvalitet štampe pamučnih pletenina različitih vrsta prepletaja putem određivanja makroneuniformnosti i kvaliteta linija odštampanih uzoraka. Rezultati istraživanja su pokazali da toplotna obrada negativno utiče na kvalitet linija, ali ima pozitivan uticaj na makroneuniformnost.
Ključne riječi: makro neuniformnost, sito štampa, kvalitet linija, pamučne pletenine, različit tip prepletaja 